\title{
Iloprost reduces colonic injury in ischemic colitis in rats ${ }^{1}$
}

\author{
Iloprosta reduz o dano colônico na colite isquêmica em ratos
}

\author{
Oguzhan Karatepe ${ }^{\mathrm{I}}$, Affan Cakir II, Orçun Unal ${ }^{\mathrm{III}}$, Muharrem Battal ${ }^{\mathrm{I}}$, Gokhan Adas ${ }^{\mathrm{IV}}$, Gülcin Kamali ${ }^{\mathrm{V}}$, Ahu Kemik ${ }^{\mathrm{VI}}$, Timucin \\ Aydin', Sedat Kamali $^{\text {VII }}$, Servet R. Karahan ${ }^{\text {VIII }}$, Murat Aksoy ${ }^{\text {IX }}$ \\ ${ }^{1}$ Research performed at Experimental Medical Research Center, İstanbul University, Turkey. \\ ${ }^{I}$ MD, Ass. Prof., Okmeydani Research Hospital General Surgery Department, Istanbul, Turkey. Main author, designed the research and analyzed the \\ data. \\ ${ }^{\text {II }}$ MD, Resident of General Surgery, Okmeydani Research Hospital General Surgery Department, Istanbul, Turkey. Surgical procedures and collection \\ of data. \\ III MD, Okmeydani Research Hospital,Vascular Surgery Department, Istanbul, Turkey. Surgical procedures. \\ ${ }^{\text {Iv }} \mathrm{MD}$, Associate Professor, Okmeydani Research Hospital General Surgery Department, Istanbul, Turkey. Revision of the study. \\ ${ }^{\vee}$ MD, Okmeydani Research Hospital, Pathology Department, Istanbul, Turkey. Performed histological analysis. \\ ${ }^{V 1}$ MD, Cerrahpasa Medical School, Department of Biochemistry, Istanbul University, Istanbul, Turkey. Performed biochemical results. \\ ${ }^{\mathrm{VII}} \mathrm{MD}$, Okmeydani Research Hospital General Surgery Department, Istanbul, Turkey. Performed statistical evaluation. \\ ${ }_{\text {VIII }}$ MD, Full Professor, Okmeydani Research Hospital General Surgery Department, Istanbul, Turkey. Analyzed the data and critical revision. \\ Ix MD, Associate Professor, Istanbul Medical School General Surgery Department, Istanbul University, Turkey. Designed the research.
}

\begin{abstract}
Purpose: Evaluate the effects of iloprost administration in the early period of ischemic colitis and the mechanism that how these effects develop. Methods: Thirty two Wistar albino female rats with an average weight of $220 \mathrm{~g}$ were divided into four groups of eight rats. In group 1 the rats were given iloprost and sacrificed after 24 hours and in group 2 they were sacrificed after 24 hours without any iloprost. The rats in group 3 were administrated iloprost and sacrificed after 72 hours and in group 4 they were sacrificed at $72^{\text {th }}$ hour without iloprost. The differences between the groups as tissue damage, vascularization or apoptosis were assessed statistically. Results: Oxidative damage and apoptosis were less pronounced and vascularization was better developed in rats that were given iloprost and sacrificed at $24^{\text {th }}$ hour later in contrast to the rats that were not treated with iloprost. But there was no statistical difference among the groups at $72^{\text {th }}$ hour. Conclusion: Iloprost inhibited leucocyte infiltration, decreased proinflammatory cytokines and enhanced angiogenesis so that the oxidative stress and inflammatory response decreased resulting in lesser tissue damage.
\end{abstract}

Key words: Colitis, Ischemic. Iloprost. Epoprostenol. Arachidonic Acid. Prostaglandins. Rats.

\section{RESUMO}

Objetivo: Avaliar os efeitos da administração de iloprosta no período precoce da colite isquêmica e o mecanismo da evolução destes efeitos. Métodos: Trinta e dois ratos Wistar fêmeas em torno de $220 \mathrm{~g}$ foram distribuídos em quatro grupos de oito ratos. No grupo 1 administração de iloprosta e sacrificados após 24 horas; no grupo 2 foram sacrificados após 24 horas sem iloprosta; no grupo 3 foi administrado iloprosta e sacrificados após 72 horas; no grupo 4 foram sacrificados após 72 horas sem Iloprosta. As diferenças entre os grupos no referente a dano tecidual. vascularização ou apoptose foi apurada estatisticamente. Resultados: Dano oxidativo e apoptose foram menos acentuados e a vascularização foi melhor nos ratos que receberam iloprosta e sacrificados após 24 horas em contraste com os ratos que não receberam iloprosta. Porém, não houve diferença estatisticamente significante entre os grupos de 72 horas. Conclusão: Iloprosta inibe infiltração leucocitária, diminui a ação inflamatória de citoquinas e estimula angiogênese resultando em menor dano tecidual.

Descritores: Colite Isquêmica. Iloprosta. Epoprostenol. Ácido Araquidônico. Prostaglandinas. Ratos. 


\section{Introduction}

Ischemic colitis is the tissue damage and inflammation that occurs as a result of insufficient blood supply to the colon and it was reported for the first time by Boley et al. ${ }^{1}$ almost $90 \%$ of the cases are 60 years or older but it can also occur in younger people. Since it may be self limiting and the diagnosis is usually made by suspicion the exact incidence can not be estimated. The insufficient blood supply may be due systemic circulatory abnormalities that induce hypo-perfusion such as congestive heart failure or shock but it may also due to local factors like mesenteric vasoconstriction or obstruction as well. The clinical picture may vary from abdominal distention to acute abdomen. Mild cases may respond to bowel rest, intravenous hydration and antibiotics but severe cases may result in intestinal gangrene, perforation and sepsis. There is yet no effective treatment modality neither in ischemic nor ischemia-prone cases.

Iloprost is a synthetic stable long acting prostacyclin (PGI) analogue that exerts its effects in the endothelium. Within normal blood pressure range it has a selective mesenteric vasodilatator effect ${ }^{2}$. The half life of iloprost is 4 minutes and it has an elimination duration of 30 minutes. It decreases the thrombocyte aggregation, leukocyte activation and chemotaxis and suppresses the superoxide anion production. It is also a potent vasodilatator. Manasia et al. ${ }^{3}$ reported that low dose $(0.075 \mu \mathrm{g} /$ $\mathrm{kg} / \mathrm{min}$ ) iloprost increased the superior mesenteric blood flow in a systemic hypotension model cused by septic shock. Iloprost was also reported to have liver and kidney sparing properties in ischemia-reperfusion damage $\mathrm{e}^{4,5}$. In patients with critical limb ischemia iloprost increased the endothelial progenitor cells in vivo and induced angiogenesis ${ }^{6}$. Iloprost was also reported by Lehman et $a .^{7}$ that it has a protective effect against endotoxin induced intestinal damage in rats and that was attributed to the decrease in leucocyte adhesion in the circulation and decrease in oxitadive damage by inhibition of proinflammatory cytokines such as TNFalpha and IL-6 $6^{8,9}$.

It is also reported that prostacyclin has stimulatory effects on angiogenesis ${ }^{10}$. The angiogenic function of the human endotalial progenitor cells (EPG) is closely associated with the arachiadonic acid metabolism and prostocylin biosynthesis. The in vivo and in vitro angiogenic capacity of EPG was shown to be related with the endogenous prostocylin levels produced by EPG ${ }^{11}$.

Iloprost is reported in the literature as it has protective effects on tissue damage by the way that it induces angiogenesis and is cytoprotective, increases intestinal blood flow and diminishes neutrophil aggreagation. But there is no study yet that explored its clinical or experimental effects on ischemic colitis. We aimed to study the effects and the mechanisms of action of the early administration of iloprost on ischemic colitis.

\section{Methods}

The study was approved by the ethical committee for the research on the animals and run in the laboratories for experimental research in Istanbul University between October 2009 and January 2010.

Thirty two Wistar albino female rats with an average weight of $220 \mathrm{~g}$ were used in the study. They were kept in individual cages for 12 hours day and 12 hours night pattern and were fed normal diet in the pre-and postoperative period.

The rats were randomized into 4 groups so that each group has 8 rats and ischemic colon was formed in each rat.

Group 1: rats were given iloprost and were sacrificed at $24^{\text {th }}$ hour.

Group 2: rats were sacrificed at $24^{\text {th }}$ hour but not given iloprost.

Group 3: rats were given iloprost and were sacrificed at $72^{\text {th }}$ hour.

Group 4: rats were sacrificed at $72^{\text {th }}$ hour but not given iloprost.

The rats were put under anesthesia by giving $10 \mathrm{mg} /$ $\mathrm{kg}$ ketamine injection intraperitoneally. The incision site was shaved and cleaned by $10 \%$ poviodine-iodine solution. Following laparatomy the ischemic colon was formed by ligating and cutting the vessels in the mesenteric tissue supplying about 2 to $4 \mathrm{~cm}$. area of the distal colon.

Rats in group 1 and 2 were subjected to $2 \mu \mathrm{g} / \mathrm{kg}$ iloprost (Iloprost $20 \mu \mathrm{g} / \mathrm{ml}$; Schering, Berlin) by intravenous infusion.

The rats in groups 1 and 2 were sacrificed at $24^{\text {th }}$ hour and the rats in groups 3 and 4 were sacrificed at $72^{\text {th }}$ hour. Tissue was sampled from the experimental ischemic colon for biochemical and histopathological study.

\section{Iloprost therapy}

The treatment dosage of the iloprost in the treatment of ischemic colitis is not present in the literature. The dosage was calculated by reviewing literature about the amount of iloprost that was effective on the ischemic tissue and the amount was given as a single dose after the surgery iloprost was administrated in the early period after the laparatomy to the rats in groups 1 and $3^{12,13}$. 


\section{The assessment of the oxidative damage}

Tissue samples were fragmented to small pieces homogenized by $1 / 5$ (W/V) phosphate buffered saline solution. The values were measured by Shimada $1601 \mathrm{UV} /$ V1s spectrophotometry (Shimada, Japan) using Lowry and Rosenbraugh method. The protein concentration was calculated according to the Lowry method.

\section{The measurement of malondialdehyde (MDA)}

The measurement of MDA was performed by tributyric acid method. $1 \mu \mathrm{mol} / \mathrm{L}$ Ferrumsulphate at $\mathrm{pH} 2.0$ was added to the solution and the absorption was recorded at lightwave $535 \mathrm{~nm}$. The normal value of MDA in the tissue was accepted as $<1.0 \mu \mathrm{mol} / \mathrm{L}$.

The measurement of nitric-oxide (NO)

NO was calculated by the calorimetric method (Boehringer Mannheim Kit; Kat no: 01756281). The normal value for NO within tissues was accepted as $<0.5 \mathrm{pg} / \mathrm{mg}$.

The measurement of vascular endothelial growth factor $(V E G F)$

The plates coated with antipoliclonal animal VEGF were used and the tests were performed by automatic Best 2000 (Biokit) microelisa. The normal value of VGEF in the tissue was accepted $<50 \mathrm{pg} / \mathrm{mL} / \mathrm{mg}$.

The measurements of tumor necrosis factor -alpha (TNF $\alpha$ ) and interleukin-6 (IL6)

The levels of TNF $\alpha$ ang IL6 within the homogenate were calculated by ELISA (Quantikene-Sensitivity-Human by RPD systems, USA). The normal value of TNF $\alpha$ was accepted as $<3.5 \mathrm{ng} / \mathrm{mg}$ and of IL6 as $<3.0 \mathrm{pg} / \mathrm{mg}$.

\section{Histopathological assessments}

The tissue samples were fixed in 10\% formaldehyde and satined by hematoxylene-eosine for microscopic examinateion under $20 \mathrm{x}$ and 100x magnification. The healing process and inflammatory response as well as granulocyte and fibroblast infiltration, necrosis, exudate formation and new capillary generation were assessed semiquantitavely. The results were

scored from 0 to $3^{14}$.

$$
\begin{aligned}
& 0 \text { No change } \\
& 1 \text { Mild changes } \\
& 2 \text { Moderate changes } \\
& 3 \text { Dense changes }
\end{aligned}
$$

\section{Statistical evaluation}

The results were assessed as mean and standard deviation. The data for the groups were analyzed by Mann Whitney-U tests and the multiple variable data between the groups were analyzed by post-hoc test (Tukey's HSD test). $\mathrm{P}<0.05$ was accepted as statistically significant. General assessment of the data was performed by the computer program Statistical Package for the Social Sciences for Windows (SPSS for windows 11.5. SPSS, Chicago, Il; USA).

\section{Results}

No mortality occurred among the study animals. The rats were sacrificed 24 and 72 hours after the performance of colonic ischemia. Biochemical values and comparisions were given as tables.

When biochemical data were analyzed the differences in the levels of TNF $\alpha$ and IL6 were found to be statistically significant ( $\mathrm{p}=0.029$ for both). MDA and NO levels as the important parameters of oxidative damage were significantly different in group 1 in contrast to group $2(p=0.001$ and $p=0.002)$. Also the levels of VEGF at $24^{\text {th }}$ hour was significant in group 1 in contrast to group 2 (Table 1 ).

TABLE 1 - Statistical comparision of the data between groups 1 and 2 .

\section{GROUP 1}

\section{MEAN SD}

0,627

TNF alfa

$$
0,530
$$

0,147

0,984

0,123

0,029

$\begin{array}{crrrrr}\text { NO } & 101,171 & 3,396 & 135,625 & 5,181 & 0,001 \\ \text { MDA } & 1,753 & 0,227 & 2,300 & 0,379 & 0,002 \\ & & & & & \\ \text { VEGF } & 2,864 & 0,312 & 2,014 & 0,382 & 0,002 \\ \text { CAS } & 22,929 & 1,533 & 30,445 & 1,463 & 0,002\end{array}$


The level of caspase-3, an indicator of apoptozis, was found to be lower at $24^{\text {th }}$ hour in group 1 compared to group 2 $(\mathrm{p}=0.002)$. But there were no satatistically significant difference in the caspase-3, IL6, MDA or VEGF levels at $72^{\text {th }}$ hour $(p=0.620$, $\mathrm{p}=0.06, \mathrm{p}=0.65, \mathrm{p}=0.08)$. TNF $\alpha$ and NO levels were lower in group 3 at $72^{\text {th }}$ hour $(\mathrm{p}=0.04, \mathrm{p}=0.001)$ (Table 2$)$.

TABLE 2 - Statistical comparision of the data between groups 3 and 4 .

\section{GROUP 4}

MEAN

$\begin{array}{crrrrr}\text { IL 6 } & 1,087 & 0,117 & 1,047 & 0,147 & 0,06 \\ \text { TNF alfa } & 1,346 & 0,210 & 0,530 & 0,089 & 0,04 \\ \text { NO } & 149,286 & 9,499 & 101,171 & 3,396 & 0,001 \\ \text { MDA } & 2,743 & 0,196 & 2,353 & 0,227 & 0,65 \\ & & & & & \\ \text { VEGF } & 2,345 & 0.432 & 2,554 & 0.513 & 0.620 \\ \text { CAS } & 35,741 & 0,848 & 34,634 & 1,533 & 0,08\end{array}$

\section{Histopathological results}

The tissues were analyzed by an independent blinded pathologist. Epithelization, monocyte and neutrophil infiltration, necrosis and capillary proliferation were assessed. All the parameters were statistically higher in group 1 compared to group 2 (monocyte infiltration $\mathrm{p}=0.020$, neutrophil infiltration $\mathrm{p}=0.42$, capillary proliferation $\mathrm{p}=0.001$ ) (Figures 1 and 2) (Table 3).

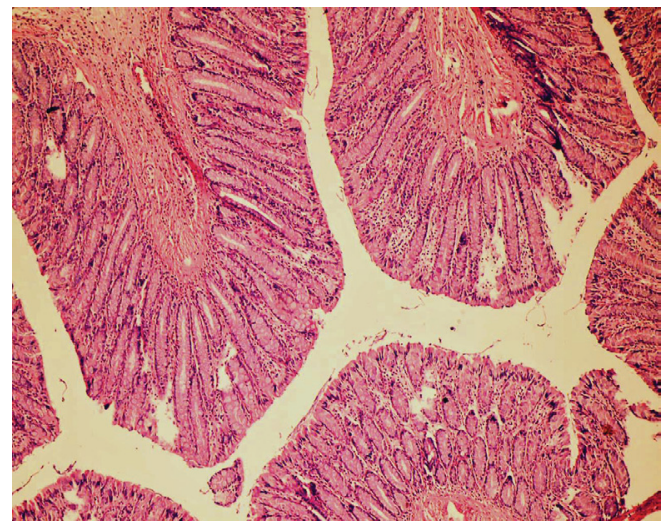

FÍGURE 1 - Leucocyte and lymphocyte infiltration in mucosa and submucosa in ischemic colitis (Hematoxylene-eosin staining X100 magnification).

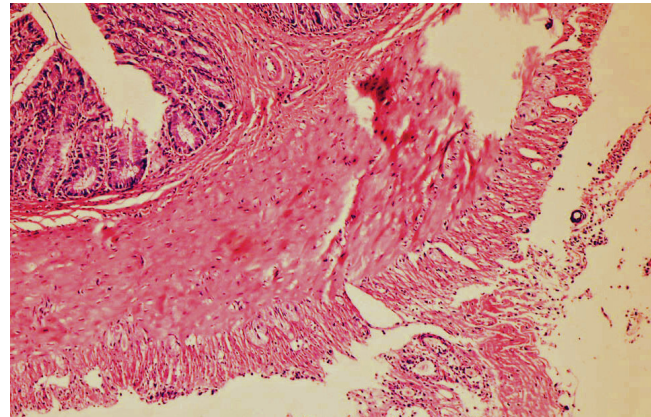

FIGURE 2 - Leucocyte and lymphocyte infiltration in mucosa and submucosa in ischemic colitis terated with iloprost ( Hematoxylene-eosin staining X100 magnification).

TABLE 3 - Statistical comparision of histopathological data between groups 1 and 2 .

$\begin{array}{cccccc}\begin{array}{c}\text { Early } \\ \text { sacrificed } \\ \text { group }\end{array} & \text { MEAN } & \text { SD. } & \text { MEAN } & \text { SD. } & \text { P } \\ \begin{array}{c}\text { Netrophil } \\ \text { infiltration }\end{array} & 2,75 & +/-0,46 & 1,875 & +/-0,64 & 0.042 \\ \begin{array}{c}\text { Monocyte } \\ \text { infiltration }\end{array} & 2,5 & +/-0,75 & 1,375 & +/-0,74 & 0.020 \\ \text { Epithelization } & 0,75 & +/-0,46 & 1,125 & +/-0,35 & 0.065 \\ \text { Necrosis } & 1,62 & & 1,125 & +/-0,64 & 0.089 \\ \begin{array}{c}\text { Capillary } \\ \text { proliferation }\end{array} & 3,125 & +/-0,64 & 2,5 & +/-0,75 & 0.001\end{array}$

But the results at $72^{\text {th }}$ hour did not show any significance $(\mathrm{p}>0.05)$

\section{Discussion}

Systemic or local factors that cause decreased intestinal blood circulation may result in ischemic colitis, a life threatening intestinal inflammation and damage. It is most frequently obderved in the colon. In contrast to small bowel ischemia there is rarely a major arterial or venous obstruction in colonic ischemia which is usually accompanied by small vessel pathology or diminished blood flow. Vascular disorders, diabetes mellitus, vasculitis and hypotension may play role in the etiology. Ligation of inferior mesenteric artery during abdominal aortic surgery or in colorectal surgery increases the predisposition of the colon to ischemia. Thrombosis or emboli can also result in ischemia.

Ischemic colitis is more frequent on the splenic flexura area of the colon and the treatment depends on the clinical presentation. Colonic ischemia usually respond to the medical therapy compared to the small bowell counterpart. A report from Madrid concluded that there was a hundred percent viability in the 
colonic mucosa if therapy started early among the 21 patients with superior mesenteric artery embolism but the viability decreased by postponed therapy to $56 \%$ after 12 hours and to $18 \%$ after 24 hours. This study strongly recommends the early start of the therapy ${ }^{15}$ Bowel rest and broad spectrum antibiotics are among the mainstays of the therapy and $80 \%$ of the patients recover eventually. If the hypotension is the cause of the clinical picture then it should rapidly treated to the normal hemodynamic parameters. With no response to the medical therapy after 2-3 days or should the clinical picture of the patient deteriorates then surgical exploration is indicated. Mortality may be 50 to $80 \%$ even with the best treatment. The recovery of the oxygen supply to the ischemic colon is the main aim during the therapy. In addition to the normal vascular supply promotion of the angiogenesis to the ischemic wound healing is necessary and can be observed by the levels of the VEGF in the molecular level. Di Stefano et al. ${ }^{6}$ reported that iloprost increased the levels of VEGF and promoted the angiogenesis in vivo so that the progenitor endothelial cell number expanded and ischemic limbs showed clinical improvement. We found that early administration of iloprost enhanced VEGF production in the tissue and there was a statistically significant increase compared to the control group (group 1 with iloprost therapy after ischemia vs. group 2 without iloprost therapy) $(\mathrm{p}=0.002)$ but there was no difference after 72 hours $(\mathrm{p}=0.6)$ Histopathologically increased levels of vascularization was observed in group 1 at $24^{\text {th }}$ hour that and although the increase was sustained even at 72 hours it was not statistically significant.

When the ischemia advances the mediators are secreted at the cellular level that result in tissue injury and oxidative damage. The cells proceed to the apoptosis which is a programmed cellular death required for physiologic homeostasis ${ }^{16}$. Bortoletto et $a l .{ }^{17}$ claimed that ischemia increases apoptosis during intestinal ischemia and hyperbaric oxygen therapy cam protect the mucosa against the ischemia-reperfusion injury. Similarly Aslan et al reported that there is increased inflammation and apoptosis in ischemic bowel anostomoses and meselamine (5-ASA) administration decreased the inflammation in the ischemic area by suppressing the free oxygen radicals ${ }^{18}$. We found too that inflammation, oxidative damage and apoptosis is increased in ischemia produced rats. To survey the level of apoptosis at the tissue level the caspase- 3 levels were assessed by biochemical methods. The caspase family activates a broad spectrum of genes that play a role in the synthesis of proinflammatory cytokines and acute phase proteins. In addition caspase- 3 activity can use as a measure of apoptozis ${ }^{19}$. The caspase- 3 activity was significantly different in iloprost given group 1 at $24^{\text {th }}$ hour compared to the control group 2 but this difference disappeared at $72^{\text {th }}$ hour. This can be translated that iloprost decreases the apoptosis in the early period of ischemia. Apoptozis is a complex process but we failed to prove the exact mechanism how the iloprost produced anti-apopitotic activity. The anti-inflammatory mechanism, increased vasculariztion or antioxidative protection all may play a role. Manasia et al. ${ }^{3}$ showed that administration of $0.18 \mu \mathrm{g} / \mathrm{kg} /$ min iloprost to the pigs subjected to septic shock increased the mesenteric perfusion without affecting mean arterial pressure by increasing cardiac output and increasing superior mesenteric artery blood flow. The same study also gave the information that the inflammation produced by endotoxic shock was diminidhed wit the use of iloprost. We found histopathologically that inflammatory cell activation was lower and enhancement of vasculariztion was better in the iloprost givengroup. The results were supported by biochemical survey and early administration of iloprost was proven even to be futher effective.

Iloprost is long acting stable prostacycline (PGI2) analogue. PGI2 is an endothelial cyclooxygenase function product that decreases thrombocyte aggregation, leucocyte activation, chemotaxis and superoxide anion production. It is a potent vasodilatator ${ }^{20}$ by relaxing the vascular tone it prevents vascular obstruction and helps the vessels carry more blood to the tissue. Iloprost decreases the blood viscosity, dissolves plugs and prevents aggregation of shed off endothelial cells ${ }^{21,22}$. Prostaglandins enhance the blood flow in ischemia-reperfusion injury in skeletal muscles ${ }^{22}$. Iloprost had therapeutic effects compared to placebo administratin in patients with diabetic feet ulcers ${ }^{23-25}$. The patients complained lesser pain and improved ulcers with clinically proven decrease in the risk of amputation both during the teherapy and also in the 3-6 month follow-up period after the treatment ${ }^{26}$. Iloprost and propentoxyphylinne reduces the macrophage produced IL6 and TNF $\alpha^{27-32}$. It coordinates the production of genes that control cellular growth and inflammation and decreases productions of cytokines in vitro. In addition to its vasodilatator and antiaggregating effects, it may also has anti-inflammatory properties $^{33}$. Iloprost can be administrated as through inhalational route or by intravenous infusion ${ }^{34}$. The requisite for infusion makes patient compliance difficult and inpatient treatment is required ${ }^{34,35}$. We introduced iloprost intreperitoneally at a dose of $2 \mu \mathrm{g} / \mathrm{kg} / \mathrm{min}$ since it is very difficult to infuse the drug intravenously for a long time in rats. K.Vasiliadis also used the drug intraperitoneally at the same dosage to counteract the side effects of the chemotherapeutic agents and to improve the healing of the colonic anastomoses ${ }^{12}$. We had set forth the study by reviewing the literature for the beneficial effects of iloprost and conclude that it has diminished 
the oxidative damage, decreased proinflammatory cytokines but enhanced angiogenesis so that it has especially prevented the ischemic damage in the early period histopathologically. The main shortfall of the study is that we could not identify the mechanisms by which the iloprost produced its protective effects.

\section{Conclusions}

\section{Oxidative damage, apoptosis and increased} myeloperoxidase (MPO) activity contributed to tissue damage in ischemic colon. Additionally increased IL6, NO, caspase-3i MDA and TNF $\alpha$ levels were interrelated with the ischemic injury. Iloprost was found to have protective properties if administrated in the early period of ischemic colitis. It inhibited leucocyte infiltration, decreased proinflammatory cytokines and enhanced angiogenesis so that the oxidative stress and inflammatory response decreased resulting in lesser tissue damage.

\section{References}

1. Boley SJ, Schwartz S, Lash J, Sternhill V. Reversible vascular occlusion of the colon. Surg Gynecol Obstet. 1963;116:53-60

2. Manasia A, Kang H, Hannon E, Lu Y, Oropello J, Leibowitz A, Stein $\mathrm{J}$, Benjamin E. Intravenoz iloprost increases mesenteric blood flow in experimental acute nonocclusive mesenteric ischemia. Crit Care Med. 2002;30:2528-34.

3. Manasia A, Kang H, Hannon E, Lu Y, Oropello J, Leibowitz A, Stein $\mathrm{J}$, Benjamin E. Intravenous iloprost increases mesenteric blood flow in experimental acute nonocclusive mesenteric ischemia. Crit Care Med. 1997;25(7):1222-7.

4. Gedik E, Girgin S, Obay BD, Ozturk H, Ozturk H, Buyukbayram H. Iloprost, a prostacyclin analogue, reduces liver injury hepatic ischemia-reperfusion in rats. Acta Cir Bras. 2009;24(3):226-32.

5. Sahsivar MO, Narin C, Kiyici A, Toy H, Ege E, Sarigül A. The effect of iloprost on renal dysfunction after renal I/R using cystatin $\mathrm{C}$ and beta2-microglobulin monitoring. Shock. 2009;32(5):498-502.

6. Di Stefano R, Barsotti MC, Mellilo E, Iorio M, Santoni T, Armani $\mathrm{C}$, Dell'omodarme M, Ristori C. The prostacyclin analogue iloprost increases circulating endothelial progenitor cells in patients with critical limb ischemia. Thromb Haemost. 2008;100(5):871-7.

7. Lehmann C, König JP, Dettmann J, Birnbaum J, Kox WJ. Effect of iloprost, a stable prostacyclin analog, on intestinal leucocyte adherence and microvascular blood flow in rat. Crit Care Med. 2001;29(7):1412-6.

8. Czeslink EG, Simm A, Grong S, Silber E, Sablotzki A. Inhibition of intracellulertumour necrosis factor (TNF) $-\alpha$ and interleukin-6 production in human monocytes by iloprost, Eur J Clin Invest. 2003;33:1013-7.

9. Kanayama T, Kimura Y, Mizogami S. A new prostacyclin analog, KP10614, inhibits platelet-polymorphonuclear leukocyte interaction and limits experimental infarct size in rat heart. J Pharmacol Exp Ther. 1993;266:344-9.

10. Buchanan FG, Chang W, Sheng H, Shao J, Morro JD, Dubois RN. Up-regulation of the enzymes involved in prostacyclinsynthesis via ras induces vascular endothelial growth factor. Gastroenterology. 2004; 1275:1391-400.
11. He T, Lu T, d'Uscio LV, Lam CF, Lee HC, Katusic ZS. Angiogenic function of prostacyclin biosynthesis in human endotelial progenitor cells. Circ Res. 2008;103(1):80-8.

12. Vasiliadis K, Pramateftekis MD, Blouhos K, Mantzoros I, Koliakos G, Zaraboukas T. Effect of iloprost on impaired anastomotic healing caused by 5 -flouracil plus leucovorin. Dis Colon Rectum. 2007;50:899-907.

13. Bostanoğlu S, Dinçer S, Keskin A, Dursun A, Serim Ç. Benefical effect of iloprost on impaired colonic anastomotic healing induced by intraperitoneal 5 -fluorouracil infusion. Dis Colon Rectum. 1998;41:642-8.

14. Chiu CJ, McArdle AH, Brown R, Scott HJ, Gurd FN. Intestinal mucosal lesion in low-flow states. I. A morphological, hemodynamic and metabolic reappraisal. Arch Surg. 1970;101(4):478-83.

15. Martinez L, Carvajosa M, Sacco E, Martinez O, Molina E. Embolectomy in mesenteric ischemia. Rev Esp Enferm. 1993;83:351-4.

16. Potten CS, Wilson JW, Booth C. Regulation and significance of apoptosis in the stem cells of the gastrointestinal epithelium. Stem Cells. 1997;15(2):82-93.

17. Bertoletto PR, Chaves JC, Fagundes AT, Simões RS, Oshima CT, Simões MJ, Fagundes DJ. Effect of different periods of hyperbaric oxygen on ischemia-reperfusion injury of rat small bowell. Acta Cir Bras. 2008;23(1):11-5.

18. Aslan A, Temiz M, Hakverdi S, Polat G, Tümer C, Temiz A, Canbolat E. Effect of mesalamine on healing in experimental colon anastomosis: a randomised experimental study. Int J Surg. 2008;6(1):40-4.

19. Kim NH, Kang PM. Apoptosis in cardiovascular diseases: mechanism and clinical implications. Korean Circ. 2010;40(7):299305.

20. Ahmet B, Vefa Ö, Bir F, Hülya A. Vitamin C and iloprost attenuate the lung injury caused by ischemia or reperfusion of the lower extremities of rats. Ann Vasc Surg. 2006;20:49-55.

21. Mazzone A, Cusa C, Bucci L, Vezzoli M. The effects of iloprost infusion on microcirculation is independent of nitric oxide metabolites and endothelin-1 in chronic peripheral ischaemia. Eur J Clin Invest. 1999;29:1-5.

22. Rowlands TE, Gough MJ, Homer-Vanniasinkam S. Prostoglandins have solutery role in skeletal muscle ischemia reperfusion injury? Eur Vasc Endovasc Surg. 1999;18:439-44.

23. Brock FE, Abri O, Baitsch G, Bechara G, Beck K, Corovic D, Diehm C, Marshall M, Rahmel B, Scheffler P, et al. Iloprost in the treatment of ischemic tissue lesions in diabetics. Results of a placebocontrolled multicenter study with a stable prostacyclin derivative. Schweiz Med Wochenschr. 1990;120(40):1477-82. German.

24. Eldor R, Raz I, Ben Yehuda A, Boulton AJ. New and experimental approaches to the teratment of diabetic foot ulcers: a comphrehensive rewiew of emerging treatment strategies. Diabet Med. 2004;21(11):1161-73

25. Duthois S, Ceilleux N, Benosman B, Levesque H. Tolerance of iloprost and results of treatment of chronic severe lower limb ischemia in diabetic patients. Diabet Metab. 2003;29(1):36-43.

26. Veroux P, Veroux M, Macarone M, Bonanno MG, Tumminelli MG. Efficacy of a novel method of intravenous infusion of the prostaglandin analogue iloprost for the treatment of lower-limb critical ischemia: An open-label, nonrandomized study in two cohorts. Curr Ther Res. 2004;65(3):255-65.

27. Jung S, Donhauser T, Toyka KV, Hartung HP. Propentofylline and iloprost suppress the production of TNF-alpha by macrophages but fail to ameliorate experimental autoimmune encephalomyelitis in Lewis rats. J Autoimmun. 1997;10(6):519-29.

28. Czeslick EG, Simm A, Grond S. Inhibition of TNF-alpha and IL-6 
production inhuman monocytes by iloprost. Eur J Clin Invest. 2003;33:1013-7.

29. Lehmann C, König JP, Dettmann J, Birnbaum J, Kox WJ. Effects of iloprost, a stable prostacyclin analog, on intestinal leukocyte adherence and microvascular blood flow in rat experimental endotoxemia. Crit Care Med. 2001;29(7):1412-6.

30. Czeslick EG, Simm A, Grond S. Inhibition of intracelluler TNFalpha and IL-6 production in human monocytes by iloprost Eur J Clin Invest. 2003;33(11):1013-7.

31. Achim J, Harald D, Nicholas T. Inhibition of TNF production in endotoxin stimulated human mononuclear leukocytes by the prostacyclin analogue iloprost: cellular mechanisms Cytokine. 1997;9(2):119-25.

32. Gao IK, Scholz P, Boehme MW, Norden C, Lemmel EM. A 7-day oral treatment of patients with active rheumatoid arthritis using the prostacyclin analog iloprost: cytokine modulation, safety and clinical effects. Rheumatol Int. 2002;22(2):45-51.
33. Di Renzo M, Pieragalli D, Meini S, De Franco V, Pompella G, Auteri A, Pasqui AL. Iloprost treatment reduces TNF-alpha production and TNF-RII expression in critical limb ischemia patients without affecting İL6. Prostaglandins Leukot Essent Fatty Acids. 2005;73(5):405-10.

34. Anne H, Mawdsley MBE. Reynaud's and Scleroderma Association, Schearing Health Care Ltd. Available from www.reynauds.org.uk

35. Two randomised and placebo-controlled studies of an oral prostacyclin analogue (iloprost) in severe leg ischaemia The oral iloprost in severe leg ischaemia study group. Eur J Vasc Endovasc Surg. 2000;20(4):358-62.

\section{Correspondence:}

\section{Oguzhan Karatepe}

Okmeydani Training Hospital Department of Surgery

\section{Sisli/Okmeydani}

34715/Istanbul,Turkey

Phone: 00902122217777

drkaratepe@yahoo.com

Conflict of interest: none Financial source: none 